\title{
韓国・ソウルにおける景観形態と住民の景観選好意識に関する研究 A STUDY ON THE CLASSIFICATION OF LANDSCAPE AND CONSCIOUSNESS OF PREFERENCE LANDSCAPE BY INHABITANTS IN SEOUL, KOREA
}

\author{
李 衡 馥*, 佐 藤誠 治**, 金 俊 榮***, 小林 祐 司**** \\ Hyung-Bok LEE, Seiji SATO, June-Young KIM \\ and Yuji KOBA YASHI
}

\begin{abstract}
The purpose of this study is to clarify the space conditions and the landscape characteristics of Seoul City that is very dense. For this, a lot of landscape pictures were gained by the field survey. We attempted to classify the landscape by using the multivariable analysis to a data-base which is assembled from the pictures. As a result, we recognized 5 classifications of landscape, which are "Street landscape in a low-rise region ", "Street landscape in the commerce and business zone", "View landscape in low-rise residential zone", "View landscape of open space" and "High-density residential landscape". Also, we observed to clarify the evaluation of landscape by general inhabitants' consciousness in dense town space using 5 classifications of landscape and survey. A sampling survey using a questionnaire was carried out at seven areas. The following results were obtained that Inhabitants are influenced pleasantness of landscape by the open space in the city.
\end{abstract}

Keywords: urban landscape, type of landscape, evaluation of landscape, inhabitant's consciousness, preference landscape 都市景観、景観類型、景観評価、住民意識、選好景観

\section{1. はじめに}

アジアの諸都市は人口の都市集中すなわちプライマシー現象を招い ている。そして、都市の空間利用の形態は、高層で高密度な形態を示し ている。韓国の都市は、開発制限区域注1) の設定により一般的に日本都 市の3倍の密度を有していると言われている。これは、韓国の都市が都 心部の活性化を実現しているという積極的な要因でもあるが、他方では 過密な都市環境が様々な負の要因として作用しているのではないかと 思われる。ソウル特別市 (以下、ソウルと呼ぶ) において、近年大きな 課題となってきた景観形成の問題は高層で高密度な環境に起因する場 合が多い。例えば、歴史的建築物と高層ビルの問題、高層住宅群の二工 一タウンと周辺との問題、漢江と沿岸ビル群との問題に代表される自然 と人工景観の問題、高密な都市街路における環境問題などである。

最近、ソウルでは市民が快適な環境をより積極的に求めようとする傾 向から、都市景観の質を取り上げた研究が注目されており、都市景観に 関する研究は多様な広がりを見せつつある。特に、景観を公共福利の一 部分として捉えて、市民の日常的な生活環境における快適性が求められ ている。また、地域のアイデンティティを形成させる手段として、それ に応じて望ましい都市形成を誘導する管理方策の研究が進んでいる。

都市景観において景観の形成計画によって全市的な方向づけを行う 上での主要な過程は多くの人々が共通して快いとする都市景観を選び
出して実現するかにあり、都市文化をまもりながら、その都市らしい都 市景観を継承し創造していく姿勢の確立が大切であると考兄る。

つまり、都市景観は特定の個人を対象にするものではない。ある意味 では普遍性や一般性が要求されるもの、すなわち、社会的責任が非常に 要求され、多数の市民がより共感できる環境創造と考えられる。

以上のような観点から、本研究では高密度な都市空間の景観問題に着 目し、急激な経済成長によって高密・高層都市化が進み、その景観問題 が高まっているソウルを対象として、高密度な都市空間の実態々都市景 観の空間特性を探るとともに、住民の景観選好に対する意識評価構造を 把握することを目的としている。そして、今後の高密度な都市空間にお いて良好な景観を誘導するための政策展開における基礎的な知見を得 ようとしている。

\section{2. 既住の研究と本研究の位置づけ}

近年の都市景観評価に関する研究は景観評価の焦点になる客観性を 得るために様々な角度から行われている。特に、計量心理学的な手法を 応用した評価手法を中心に、様々な手法が用いられることが多い。代表 的には村川ら ${ }^{11}$ 、西名ら ${ }^{21}$ 、土肥ら ${ }^{3)}$ 、上杉ら ${ }^{4)}$ の研究が挙げられる。

また、景観を評価する前段階として、都市がどのような景観形態特 性を持っているかを正確に把握することも重要と言われている。それに
* 大分大学工学研究科 博士後期課程 $\cdot$ 工修

** 大分大学工学部建設工学科 教授. 工博

**** 韓国西京大学工学部都市工学科 教授・工博

**** 大分大学工学部建設工学科 助手. 工修
Graduate Student, Dept. of Architectural Eng., Faculty of Engineering, Oita University, M. Eng.

Prof., Dept. of Architectural Eng., Faculty of Engineering, Oita University, Dr. Eng. Prof., Dept. of Urban Eng., Faculty of Engineering, Seokyeong University, Korea, Dr. Eng.

Research Assoc., Dept. of Architectural Eng., Faculty of Engineering, Oita University, M. Eng. 
対してもメッシュデータやスライド写真やV T R P C G などを利 用した視覚的分析により景観形態特性を把握している研究も数多 くある。例えばメッシュデー夕による景観域を類型化した坂本ら5)、 佐藤ら ${ }^{6)}$ の研究などがあり、写真などを利用して分析した研究では

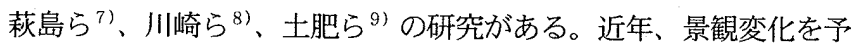
測する手段としても利用しているC GO場合は有馬ら ${ }^{10)}$ 、佐藤ら ${ }^{11}$ の研究が数多くあり、多様な研究が行われているがC Gのリアリテ イの問題で、C G 画像をそのまま景観評価の研究に使用する場合は 極めて限られた景観上の要素評価に用いられることが多い。一方、 韓国には、ソウルの景観管理のため「景観地区」をどのように活用 するかを提示し、それの指定及び運用なぞに関する具体的な研究 ${ }^{12)}$ 〜4) がみられるが筆者らが意図する都市の景観類型及び景観類型の 選好性などについては触れていない。

本研究では以上の前例に範を探りながら、都市景観画像デ一タべ 一スの構築と景観類型化によって、ソウル景観の視覚形態の特徵を 探り、住民が地域の景観を実態として評価する際、身近な地域にあ る景観から類型化した景観類型の画像を用いて選好景観と景観選 好に対する基礎的な意識評価構造を確認するものであり、本研究の 独自性もここにあると考える。

\section{3. 研究の方法}

本研究はソウルの都市空間の実態およびそこに現象する景観の形 態の特徵を探る景観形態分析と住民が満足できる都市景観を探る ための住民の選好景観を通じて基礎的な評価構造を把握する景観 選好意識分析によって成り立っている。まず、景観形態分析ではり ウルの景観写真を収集するために、調査地域を選定した上で現地調 查を行った。この調査によって撮影した景観写真をもとに、それら 画像に含まれる景観要素をデータベース化した上で、このデータベ 一スに対して、多变量解析（数量化而類分析、クラスター分析）を 適用し、景観画像の類型化を行った。そして得られた各類型の空間 分布や用途地域指定状況を観察して、その特性を把握した。

そして、景観選好意識分析では住民が地域の景観を実熊として評 価する際、選好景観に対してどのように感じているかを求めるため 景観類型分析から得られた類型画像を具体的な画像として呈示し
てアンケート調査を行った。それでこのアンケートの評価結果から 住民の景観選好意識の構造を把握した。最後は 2 つの分析から得ら れた結果を総合的に考察した。研究の主要な流れを図 1 に示す。

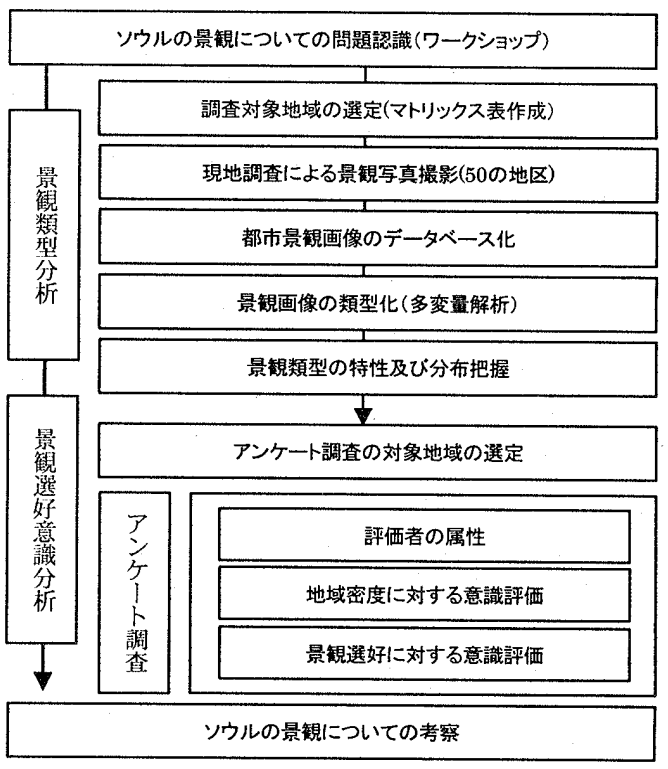

図1. 研究の流れ

\section{4. 都市景観類型分析}

\section{1 調查対象地域の抽出と現地調查}

まず、多様な都市景観画像を偏りなく収集するために景観画像の 撮影を行う調査対象地域の抽出においてマトリックス表を用いた。 マトリックス表を用いて、ソウルの多様な都市景観の空間特性を含 み、都市の全体像が組み上がるような景観画像を撮影するために都

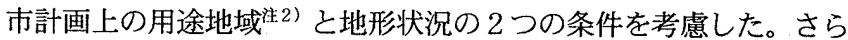
になるべく広範囲から分散した調査地域を抽出するため、ソウルの ほぼ中央を東西に流れている漢江を基準にして北部と南部で調查 地域がほぼ同数になるように配慮した。なお、用途地域として住居 地域、商業地域、工業地域、緑地地域の 4 つ、地形条件として平地、 漢江付近、山、丘陵の 4 つを取り上げた。それらの条件をもとにし て特定の条件に偏らないように 50 地区を選出した。さらに、表 1 には選ばれた調査対象地域名・用途地域・地形条件を、図 2 に調査

\section{表1. 調查対象地域名·用途地域·地形条件}

\begin{tabular}{|c|c|c|c|c|c|}
\hline No 地域名 & 用途地域 & 地形条件 & No 地域名 & 用途地域 & 地形条件 \\
\hline 1 Nowon & 住居 & 西㺮 & 26 Shillim & 商業 & 平地 \\
\hline 2 Yoshinnae & 住居 & 平地 & 27 Kangnam & 商業 & 平地 \\
\hline 3 Pyongchangdong & 住居 & 山 & 28 Samsong & 商業 & 平地 \\
\hline 4 Tongsomun & 住居 & 丘陵 & 29 Chamsil & 商業 & 平地 \\
\hline 5 An-guk & 住居 & 平地 & 30 Karak & 商業 & 平地 \\
\hline 6 Oksu & 住居 & 丘陵 & 31 Yangjae & 商業 & 山 \\
\hline 7 Konkuk University & 住居 & 平地 & 32 Kugi & 緑地 & 山 \\
\hline 8 Mok-dong & 住居 & 平地 & 33 Chongnung & 緑地 & 丘陵 \\
\hline 9 Ichon & 住居 & 河川 & 34 Susaek & 緑地 & 丘陵 \\
\hline 10 Apkujong & 住居 & 河川 & 35 Muak & 緑地 & 山 \\
\hline 11 Shinchan & 住居 & 河川 & 36 Namsan & 緑地 & 山 \\
\hline 12 Pungnap & 住居 & 平地 & 37 Children Park & 緑地 & 平地 \\
\hline 13 Sang-il & 住居 & 平地 & 38 Yongsan Family Park & 緑地 & 平地 \\
\hline 14 Pongchon & 住居 & 丘陵 & 39 Poramae Park & 緑地 & 平地 \\
\hline 15 Nangok & 住居 & 丘陵 & 40 Seoul University & 緑地 & 丘陵 \\
\hline 16 Kirum & 住居 & 丘陵 & 41 Umyon & 緑地 & 山 \\
\hline 17 Suyu & 商業 & 平地 & 42 Olympic Park & 緑地 & 平地 \\
\hline 18 Pulgwang & 商業 & 丘陵 & 43 Tobong & 緑地 & 山 \\
\hline 19 Tonam & 商業 & 平地 & 44 Seoul Dream Land & 緑地 & 平地 \\
\hline 20 Chongnyangni & 商業 & 平地 & 45 Chongsujang & 緑地 & 丘陵 \\
\hline 21 Chongno & 商業 & 平地 & 46 Changdong & 工業 & 平地 \\
\hline 22 Sungnyemun & 商業 & 平地 & 47 Songsu & 工業 & 平地 \\
\hline 23 Shinchon & 商業 & 平地 & 48 Mullae & 工業 & 平地 \\
\hline 24 Yongdungpo & 商業 & 平地 & 49 Shindorim & 工業 & 平地 \\
\hline 25 Youido & 商業 & 平地 & 50 Kuro & 工業 & 平地 \\
\hline
\end{tabular}

注) (1)丘陵は標高 40〜200m の範囲とする(参考文献12より)。(2) 河川は漢江付近を意味する。

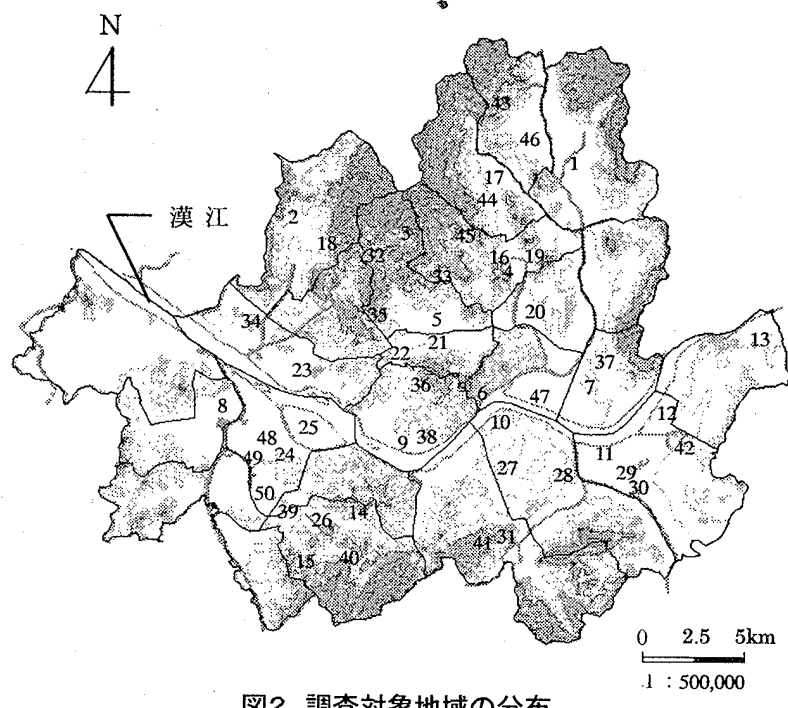

図2. 調査対象地域の分布 
表2. 景観構成要素の出現頻度

\begin{tabular}{|c|c|}
\hline 景観構成要素 & 出現数 \\
\hline 自然要素 & \\
\hline 山、兵陵 & 130 \\
\hline 河川 & 32 \\
\hline 樹木 & 153 \\
\hline 建築物 & \\
\hline 低層建築物（近景） & 119 \\
\hline 低層建築物（中景） & 108 \\
\hline 低層建築物（遠昌） & 20 \\
\hline 住居(近景) & 34 \\
\hline 住居(中景) & 55 \\
\hline 住居（遠量） & 28 \\
\hline 中層建築物（近景） & 27 \\
\hline 中層建築物 (中量) & 58 \\
\hline 中層建筑物（遠嘼） & 12 \\
\hline 高層建築物（近累） & 41 \\
\hline 高層建築物（中固） & 83 \\
\hline 高層建築物（遠景） & 55 \\
\hline 高層アパート(近景) & 31 \\
\hline 高層アパート(中景) & 95 \\
\hline 高層アパート(遠景) & 42 \\
\hline 住居群 & 49 \\
\hline 高層建築物群 & 118 \\
\hline その地(人工要素) & \\
\hline 道路 (近暴) & 146 \\
\hline 道路（中景） & 66 \\
\hline 街路樹 & 132 \\
\hline 高架道路、鉄道 & 16 \\
\hline 楿 & 24 \\
\hline 看板 & 64 \\
\hline 㩯墥、信号 & 110 \\
\hline 電柱，電線 & 112 \\
\hline 街奵 & 134 \\
\hline 鉄塔・煙突 & 26 \\
\hline クレーン & 34 \\
\hline
\end{tabular}

表3. 数量化正類によるカテゴリースコア

\begin{tabular}{|c|c|c|c|}
\hline カテゴリ & 第1軸 & 第2軸 & 第3軸 \\
\hline 山、乒陵 & 0.646 & 0.375 & 0.293 \\
\hline 河川 & 1.362 & -3.290 & 0.979 \\
\hline 樹木 & 0.806 & -0.055 & -0.102 \\
\hline 低層建築物(近量) & -0.539 & 0.418 & -1.278 \\
\hline 低層建築物(中景) & -0.159 & 0.431 & -0.467 \\
\hline 低層建築物(遠景) & 2.595 & 0.573 & 1.565 \\
\hline 住居(近暴) & 1.808 & 1.908 & -1.238 \\
\hline 住居(中暴) & 1.889 & 1.858 & -0.166 \\
\hline 住居(遠景) & 2.696 & 1.675 & 1.383 \\
\hline 中屡建築物（近景） & -1.341 & 0.756 & 2.122 \\
\hline 中绝建築物(中景) & -0.646 & 0.501 & 1.515 \\
\hline 中層建築物(遠景) & 1.334 & 1.005 & 2.413 \\
\hline 䯩層建築物(近贯) & -1.578 & 0.633 & 1.989 \\
\hline 槀層建築物(中量) & -0.883 & 0.187 & 1.475 \\
\hline 高層建築物(遠景) & -0.160 & -0.591 & 1.593 \\
\hline 高層アパート(近景) & -0.310 & -1.702 & -1.948 \\
\hline 高曆アパート(中景) & 0.380 & -1.555 & -1.015 \\
\hline 高層アパート(遠景) & 1.401 & -1.021 & 1.041 \\
\hline 住居群 & 2.150 & 1.690 & 0.447 \\
\hline 高層建築物群 & 0.728 & -1.330 & -0.329 \\
\hline 道路(近量) & -0.806 & 0.225 & -0.288 \\
\hline 道路(中県) & -0.641 & 0.025 & -0.355 \\
\hline 街路樹 & -1.158 & 0.142 & 0.253 \\
\hline 高架道路、鉄道 & 1.440 & -0.296 & 0.699 \\
\hline 橋 & 1.339 & -3.619 & 1.375 \\
\hline 看板 & -1.082 & 0.700 & -1.126 \\
\hline 標識、信号 & -1.049 & 0.157 & 0.239 \\
\hline 電柱、電線 & 0.080 & 0.408 & -1.332 \\
\hline 街灯 & -0.814 & -0.379 & 0.491 \\
\hline 鉄塔·煙突 & 0.821 & -0.386 & -0.838 \\
\hline クレーン & 0.538 & 0.242 & 0.572 \\
\hline 固有値 & 0.469 & 0.332 & 0.262 \\
\hline 相関係数 & 0.685 & 0.576 & 0.512 \\
\hline
\end{tabular}

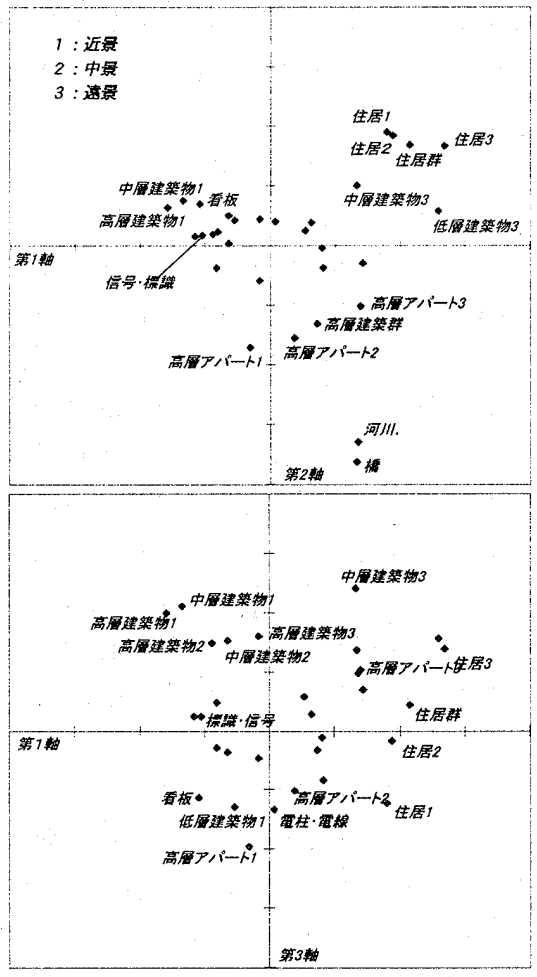

図3. カテゴリースコアの散布図
対象地域の分布を示す。現地調查は 1998 年 8 月 28 日から 9 月 1 日 の 5 日間で、調査員 6 名により実施し、最終的に 50 地区を対象に、 地区別約 15 枚を撮影して計 731 枚の景観写真を撮影礼 した。

\section{2 景観画像の整理とデータ化}

現地調査によって大量の景観画像を撮影したが、分析に使用可能 で適切な画像を選ぶため、次のことを考慮した。(1)分析するときに 同じ景観要素を重複計算することを防止するため、同一もしくは類 似画像を除く、(2)鮮明度が欠けるなど景観分析のデータとして不適 当で、補正が不可能と判断される画像を除く、(3)近景・中景・遠景 の区別ができず、景観要素の抽出ができないなどの理由で分析に適 さない画像を取り除く。この結果、各地区約 6 枚を選定して、計 296 林の画像を選定することができた。

景観というのはさまざまな景観構成要素から成り立っているもの であり、一般に景観構成要素が景観の特幑を左右するといえる。こ のような景観構成要素を認識するために選定した画像を精査し、そ の結果、表 2 に示すような 31 の景観構成要素を抽出した。さらに、 各画像における景観構成要素の有無をもとにデータベースを作成 した。データベース中においては景観構成要素が存在する場合が "1”、存在しない場合が”0"で表現されている。表 2 に示す景観構成 要素の出現頻度を観察すると、「山・丘陵」「高層アパート」「高層 建築物」が注目される。いずれの出現頻度も比較的高く、「山・丘 陵」の頻度は、ソウルに山や丘陵地が多く存在することを示してい るし、ソウル内のいたる所で「山・丘陵」を見ることができ、自然 景観における重要な要素となっていると考えられる。また、「高層 アパート」「高層建築物」の頻度は、ソウルの都市空間密度の高さ を表しているし、居住環境の高層化がなされていることがわかる。 すなわち、ソウルは高層な建築物が、高密な空間と深く関係がある と推測でき、これらは、いずれもソウルの景観を特徴づけるものと 考えられる。

\section{3 景観画像の数量化正類分析}

得られた画像から景観構成要素の構造を明らかにするために、前 項であげたデー夕に対して数量化而類を適用し、分析を実施した。 その結果、第 3 軸までの、カテゴリースコア、サンプルスコアを得 た。分析から導かれる軸は全景観画像の景観構成要素に共通して作 用する特徵を示すものである。まず、軸別にカテゴリースコアを表 3 に示す。図3 3 はテゴリースコアの散布図である。さらに、この 表 3 と図 3 のカデゴリースコアの分布をもとに、因子軸の解釈を試 みる。

\section{3.1 第 1 軸の解釈}

第 1 軸の相関係数は、0.685である。カテゴリースコアは、正の方 向に「住居 3 」「低層建築物 3 」「高層アパート 3 」「中層建築物 3 」 など、遠景の構成要素が見られる。また、住居に関しては、「住居 1」「住居 2」「住居 3」と、近景から遠景のものにかけて強い值を 示している。負の方向には「高層建築物 1」「中層建築物 1」「看板」 「標識、信号」などが見られる。つまり、近景の建築物と近景で扱 われた構成要素が強い値を示している。第 1 軸は構成要素の距離的 な特性を表しており、画像の可視領域に関係する軸であると考えら れる。以上を総合して、第 1 軸は『景観の奥行きを表す軸』と解釈 した。

\section{3.2 第 2 軸の解釈}

第 2 軸の相関係数は 0.576 である。カテゴリースコアは、正の方 向には「住居 $1 」$ 「住居 $2 」 「$ 住居 3 」住居群」などが強い值を示 している。負の方向には「橋」「河川」「高層アパート1」「高層ア

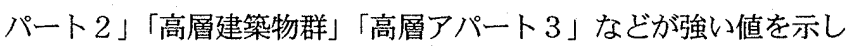
ている。つまり、負の方向は「河川」という地形的条件と「高層ア パート」という住居形態か強く反応している。また、正の方向の「住 居」は、ソウル郊外で多く見られたヴィラ(Villa)が 強い值を示し ていると考えられる。そのヴィラは丘陵地に多く見られたことから、 
第 2 軸は、郊外の地形的特性を表す軸であると考えられる。以上を 総合して、第2 軸は、『地形条件に支配された建築物の規模を表す 軸』と解釈した。

4. 3.3 第 3 軸の解釈

第 3 軸の相関係数は 0.512 である。カテゴリースコアは、正の方 向に「中層建築物 1 」「中層建築物 2 」中層建築物 3 」「高層建築 物 1 」「高層建築物 2 」高層建築物 3 」などの高層な建築物の力テ ゴリーが強い值を示している。負の方向には「高層アパート1」「低 層建築物 $1 」 「$ 住居 $1 」$ などの近景の建築物と、「電柱、電線」「看板」 など諸要素の小さいカテゴりーが強い值を示している。これより、 正の方向は大規模な建築物で構成されるスケール感の大きい空間 であると考えられる。また、負の方向は、装飾的な構成要素が目立 つ。これは、密度の高い空間であると考えられる。そこで、第 3 軸 は、構成要素の数、種類の多さなどがその特性を表す上で深く関係 していると考えられる。以上を総合して、第 3 軸は『空間の密度性 を表す軸』と解釈した。

\section{4 景観画像のクラスター分析}

得られた景観画像がごのように分類されるかを明らかにするた めに、数量化而類の結果から得られたサンプルスコアを用いて、ク ラスター分析を行った。クラスター分析は、ユークリッド平方距離 を用いたウォード法を採用した。クラスター分析ではクラスター化 の最も適当な段階でグループ数を決めることにより分析結果に重 要な影響を及ぼす。ここでは情報損失量(ESS)の変化量を参考にクラ

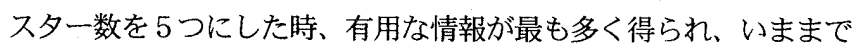
混沌としていた画像がより理解可能になった。分析結果を 5 つの景 観類型して以後これを、それぞれ「景観類型 1 」「景観類型 2 」景 観類型 3 」「景観類型 4」「景観類型 $5 」$ 表現する。また、各類型 別のカテゴリーの出現頻度数と代表的画像を表 4 に示す。

\section{5 景観類型の特性}

クラスター分析によってソウルの景観を特徴づける代表的なもの として 5 つ類型を得ることができた。まず、注目することはす心゙ ての類型において高層建築物、高層アパート、高層建築物群の頻度 の多寒はあるものの、必ず見られることである。これは、ソウルが 高密な空間特性であることを、端的に表わす結果となったと考えら れる。これに加えて各類型の特性について要約する。

\section{5. 1 景観類型 1}

類型 1 の景観画像は、眺望性が低く、空間の密度が高いと考えら れる。また、カテゴリーの出現頻度は、近景、中景の低層建築物、 看板、電柱電線などが多い。さらに、画像からの判断も加えると、 類型 1 は、主に低層建筑物で構成される街路景観と解釈できる。こ れらより、『低層地域における街路景観』と要約できる。

\section{5. 2 景観類型 2}

類型 2 の景観画像は、眺望性が低いと考えられる。また、カテゴ リーの出現頻度は、近景、中景の中層建築物、高層建築物、街路樹、 街灯などが多い。さらに、類型 2 の画像は、中、高層の建築物を中 心とする、市街地の景観画像が多い。これらのことから、『商業・ 業務地区における街路景観』と要約できる。

\section{5.3 景観類型 3}

類型 3 の景観画像は、丘陵地の眺望の良い景観画像であると判断 できる。また、カテゴリーの出現頻度は、山、樹木、住居、住居群
などが多い。全体的に、低層住居を中心とする画像が多いが、高層 建築物群の数が多いことも目に付く。これらは、良好な景観を阻害 しているようにも見受けられる。全体的には、『低層住居を中心と した眺望景観』と要約できる。

4. 5.4 景観類型 4

類型 4 の景観画像は眺望性が高く、強い地形的特性を持つ類型と 考えられる。カテゴリーの出現頻度は、河川、橋が非常に高い。高 層建築物群、高層アパートも多く現れている。また、眺望性の高さ は、河川によってできるオープンスペースの存在からくるものだと 考えられる。これらのことから、『オープンスペースから望む展望 景観』と要約できる。

4. 5.5 景観類型 5

類型 5 の景観画像は空間の密度が高い類型と考えられる。カテゴ リーの出現頻度は、近景、中景の高層アパート、高層建築物群が突 出して多く出現している。これらより、『高密な住宅地景観』と要 約した。

表4. 景観類型別のカテゴリ一出現頻度

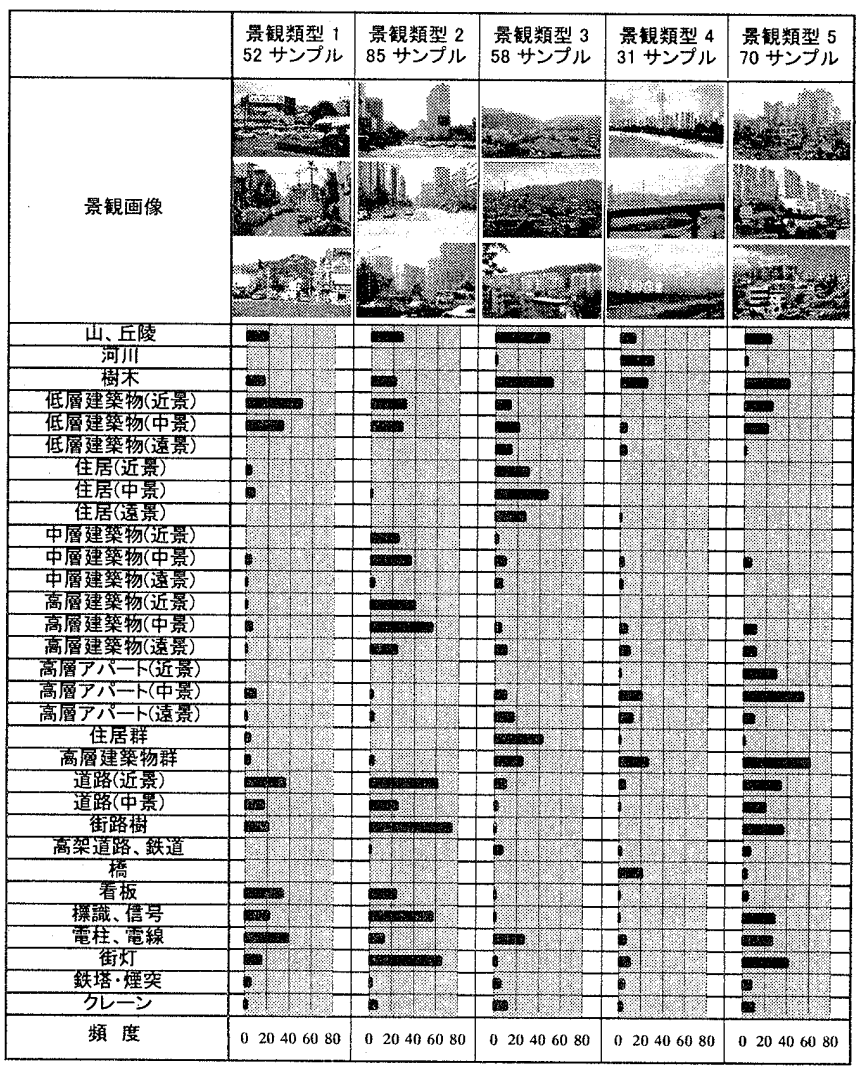

\section{6 各景観類型の分布}

各景観類型に属する撮影地点の平面分布、用途地域の割合、地形 条件の割合、景観阻害の状況を観察し、景観類型の特性を把握した。 表 5 は各景観類型を用途地域別・地形別に頻度を表したものであり、 地図上に各景観類型の分布を表示したものである。

景観類型 1 の場合はソウルの全般に広く分布している。また商業 地域、工業地域、平地の割合が高くなっているし、看板・電柱など が非常に多くみられる景観である。景観類型 2 は都心、副都心の商 業地域に多く分布し、平地の割合が高い。高層な建築物により、歴 史的な建造物が埋没している例が見られる。景観類型 3 はりウルの 
地形的な特徴である丘陵地に広く分布し、緑地地域の割合が高い。 低層建築物が密集している地域に高層建築物が近接して立地して いる例がみられる。景観類型 4 は河川の付近に広く分布し、住居地 域の割合が高い。高層アパートが視界を遮るように連立する例がよ く見られる。景観において、山やその周辺地域は景観判断に影響力 がかなり強いことがいえる。景観類型 5 はソウルの各所の丘陵、河 川付近に多く見られ、住居地域の割合が高くなつている。低層建築 物と高層建築物の隣接立地、スカイラインの破壊など様々な景観阻 害の例が見られる。

以上のことを総括すると地形条件に関しては、ソウルの地勢は平 地部が非常に多くみられる。そのため、全体的に平地の割合が高く なるという結果が出た。しかし、河川や丘陵は一部の類型に偏りを 見せていることがわかる。このことから、地形条件に関しても、用 途地域と同じく、景観の性格を特徵づける要素となっていると考え られる。勿論このことは、平面分布にも反映される結果となった。

\section{表5. 景観類型別の分布}

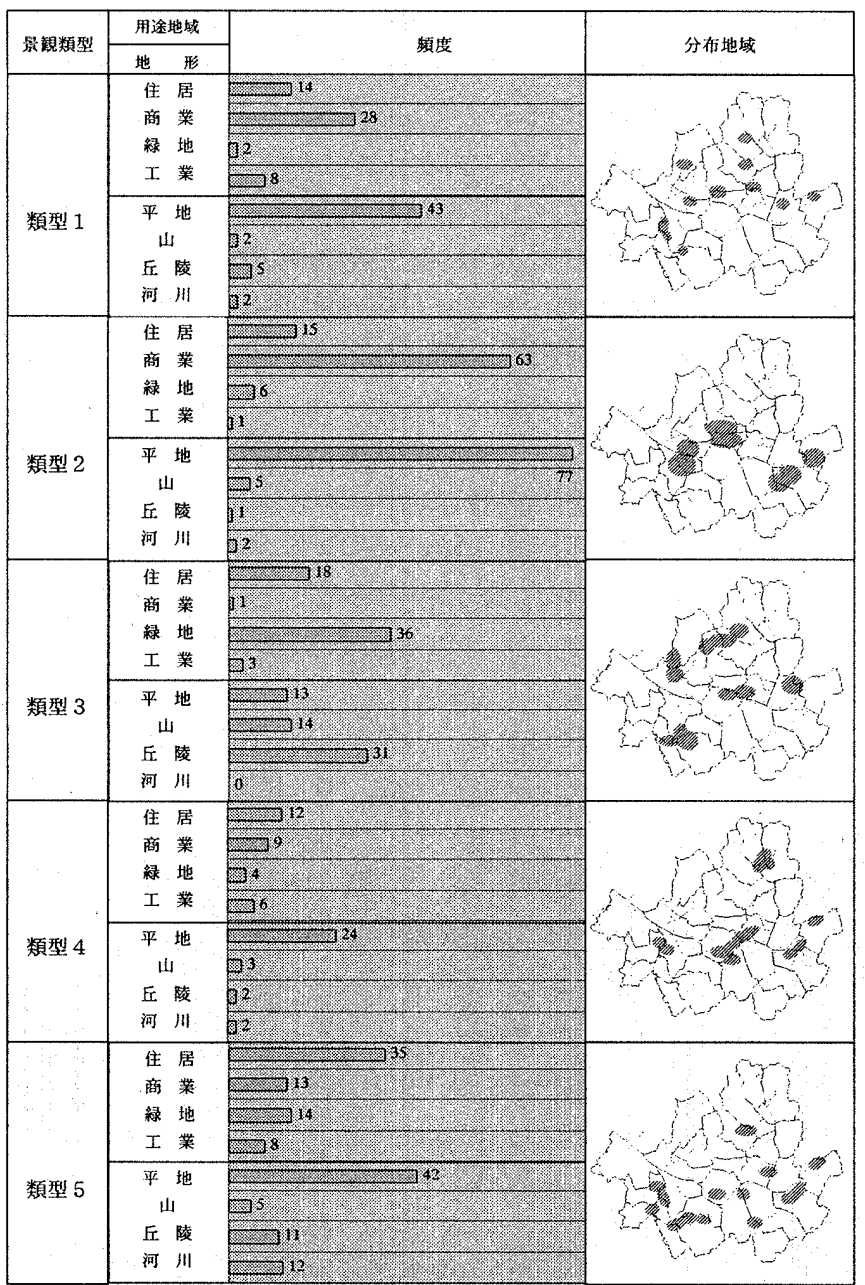

\section{5. 景観類型による住民の景観選好意識分析}

5. 1 アンケート調查概要

5. 1. 1 調查対象地区の選定

アンケートを用いた標本調査による景観選好意識分析の調查では、 まず、高密度地域の住民を対象として基礎的な密度意識を把握し、 前章で類型化した景観類型を用いて、景観の選好意識構造を把握す
る。なお、調査対象地区の選定においては多様な地区特性を有する 景観の評価を得る必要からいくつかの条件を考慮し、都市景観類型 分析の選出した 50 地区から景観類型と用途地域を考慮しながらケ 一ススタディとして計 7 つの地区をとりあげて調査を行った。

まず、調査対象地区は(1)密度計算法激4)による密度が高い区、(2)用 途地域である住居地域や商業地域や緑地地域が混在している区、(3) 地形的条件として丘陵地や平地や河川地域などをもっている区、(4) ソウルを代表する山を持っている区、(5)景観形態分析から高層アパ 一トの割合が高い区という 5 つの条件を考慮してソウルの 25 行政 区中から 3 区をケーススタディとして選定した。

その結果、漢江を基準として江北は城北区と道峰区、江南は冠岳 区が選定された。そして、都市景観類型分析によって選出された地 区から住居地域 4 ・商業地域 2 の合計 6 地区を選び、またりウルの 用途地域の中で少ない割合の工業地域である道峰区内の 1 地区を 選定した。表 6 では選定したアンケート調査対象地区の概要を示す。

\section{表6. アンケート調查対象地区の概要}

\begin{tabular}{|c|c|c|c|c|c|c|}
\hline 雷号 & 地区名 & 景観類型 & 行政区名 & 地形特性 & 用途地域 & 地区性格 \\
\hline 1 & 菄西門洞 & 䫓型 5 & \multirow{3}{*}{ 城北区 } & 兵陵地 & \multirow[t]{2}{*}{ 住居地域 } & 高歷住塞地域 \\
\hline$\frac{1}{2}$ & 筫陵了洞 & 類型了 & & 兵陵地 & & 低層住地地域 \\
\hline 3 & 東仙洞 & 類菿1 & & 龵地 & 商業地域 & 商羍地域 \\
\hline 4 & 奉天3洞 & 類型5 & \multirow{3}{*}{ 冠岳区 } & 乒陵地 & \multirow{2}{*}{ 住居地域 } & 高層住宅地域 \\
\hline 5 & 新林6洞 & 類型了 & & 平地 & & 低䅋住宅地域 \\
\hline$\frac{5}{6}$ & 新林本洞 & 類型2 & & 平地 & 商業地域 & 商業地域 \\
\hline$\frac{5}{7}$ & 會了洞 & 類型 4 & 道峰区 & 平地 & 工業地域 & 工業·住居地域 \\
\hline 番号 & 地区名 & & & 地区の半 & & \\
\hline 1 & 菄西門洞 & 地形的には丘凌地 & ๕あって、1 & 翊アパート & 安があり、商 & 域に隣接している \\
\hline$\frac{1}{2}$ & 真陵了洞近 & 近〈こソウルを代表 & 可名北漌 & が位置して & 马丘陵地で & \\
\hline 3 & 東仙洞 & 近所に大学が多い & कで店の| & とんどが若 & 万尚きの傾向 & ある。 \\
\hline 4 & 奉天洞 & 最近，大きい住宅改 & 家の再開严 & 啔業が行っ & 小る地域であ & \\
\hline 5 & 新林 6 洞 & 一般的な低層住宅 & 也域であり & 高層アパ- & ऊरほとんट゙。 & 也域である。 \\
\hline 6 & 新林本洞趣 & 覀近、中-高曆 & 增えてl & 落者の向 & D商業地域 & 3。 \\
\hline$\frac{5}{7}$ & \begin{tabular}{l|l} 
䚻了洞 & 近 \\
\end{tabular} & 近所に河川があり & & 下団地が增 & 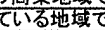 & \\
\hline
\end{tabular}

\section{1.2 調査方法}

アンケートの内容は、大別して被験者の属性／地区密度に対する 意識評価／選好景観に対する評価になっている。全質問項目は 27 項目であり、そのうち、選好景観評価ではS D法を用いた 7 段階の 評価を行った。本調査は 1999 年 8 月 23 日〜 8 31 日に対象 7 の地 区内の住民に実施した注5)。アンケートの用紙は7 地区において、そ れぞれ 55 票ずつ計 385 票を配布して有効回答は総 363 票であり、 有効回収率は $94.3 \%$ であった。調査は、調查員が各地区の住民を無 作為に選択してその場で書き込んでもらう方法によって行った。サ ンプル数は地区別にあまり差がなく平均的には 51 票であった。

\section{2 被験者の属性}

被験者の属性を把握するため、地区別にまとめたのが表 7である。 高層アパートの割合が高い東西門洞、奉天 3 洞、倉 3 洞は 20,30 代の年齢層の構成比が特に高い。これは調査対象地区における若者 の方が高層アパートに興味を持っていると考えられる。ソウルでの 7 地区の居住期間はほぼ類似しているが、現居住住宅での居住期間 は低層住居地域（貞陵 3 洞、新林 6 洞）が長期間になっている。

しかし、工業地域の倉 3 洞の場合、ソウルでの居住期間は長期間 であるが現居住住宅の居住期間は短期間である。それは、倉 3 洞が 再開発事業によって新しいアパート団地に生まれ変わり、住み替え が行われたことを表す。現居住住宅形態は用途地域に合うように建 てられているが7地区の全地区からヴィラと連立住宅と多世帯住 宅が数多く見られるのが特徴である。特に、ヴィラと連立住宅と多 世帯住宅注 6) は景観類型分析からも表れた結果であって、ソウルの 住居地域景観の特徵と考えられる。 
表7. 評価者の属性

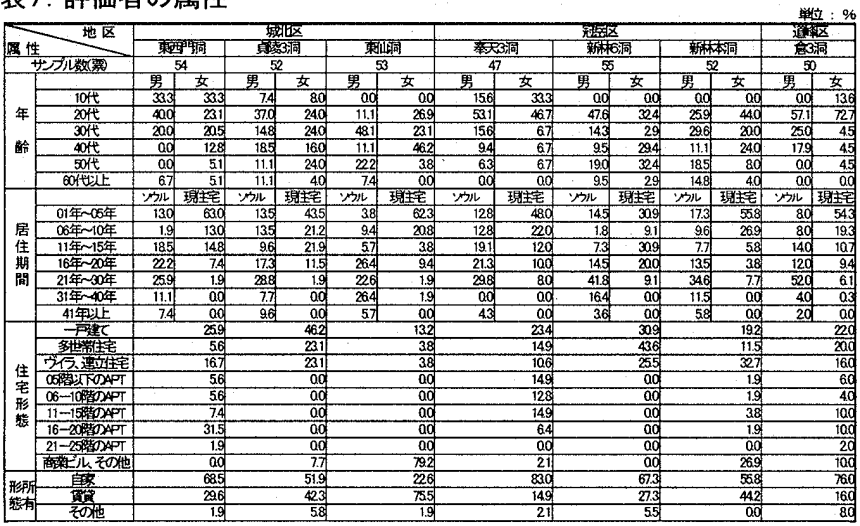

\section{3 地区密度に対する意識評価}

「居住地区内の密度感をどのくらい感じているか」という地区の 密度感(地区内における建築物の占める割合の大きさ)に対する意識 評価では、全地区においてほとんどの被験者が「地区の密度が高い」 と感じていると回答している。地区別に見ると「高い」と答えた割 合が高層住居地域である東西門洞 $38.9 \%$ 、奉天 3 洞 $46.8 \%$ 、倉 3 洞 $34.0 \%$ という高い值を示した。また、東仙洞と新林本洞は「高い」 という答えが各 $50.9 \% 、 53.8 \%$ と半分以上の割合である。すなわち、 用途地域別からみると商業地域と高層住居地域の住民が密度感に ついて高く感じていると考えられる。また、地区の密度が高くなっ た原因についての質問の結果は「商業地域と住居地域の混雑」とい う答えの割合が商業地域 (東仙洞 $60.3 \%$ 、新林本洞 $51.9 \%$ )で高い值を

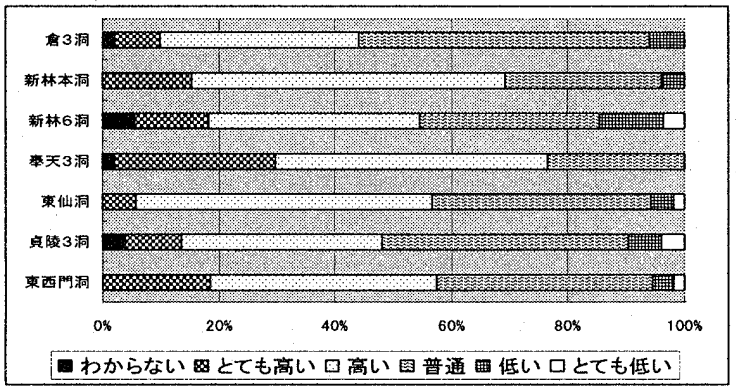

図4. 住民が感じている地区の密度

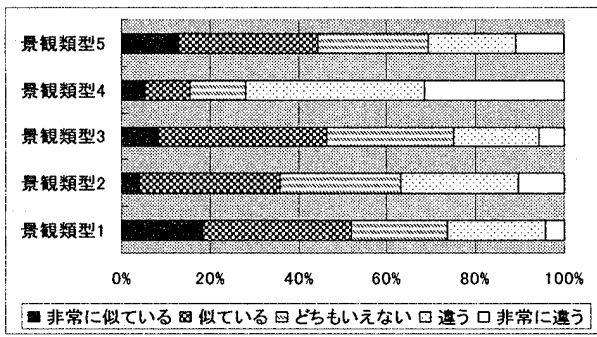

図5. 景観類型と居住地区景観の類似性

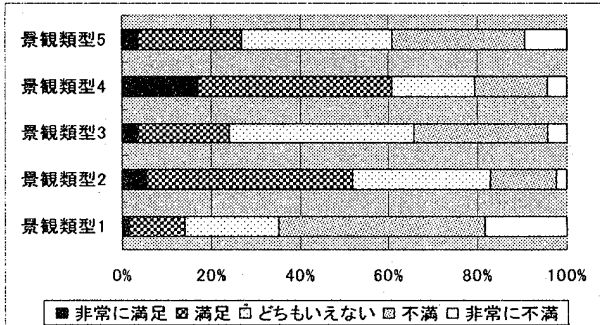

図6. 景観類型別に対する景観満足度
示した。それはソウルの商業地域が、商業と住居が分離されないま ま、一般住居地域まで拡大されていると考えられる。また、再開発・ 再建築事業の割合が東西門洞 $(55.6 \%$ )、貞陵 3 洞 $(50.3 \%$ )、倉 3 洞 (34.0\%) で高く見られたことから、漢江を中心して江北は江南より 再開発・再建築事業が激しく行われていると考えられる。

\section{4 景観選好に対する評価}

住民がある景観の魅力を判断したり、複数の景観を比較する場合 は、部分の評価を積み上げる思考だけでなく、全体的な印象を感じ たり、異質であると感じる部分に対して特別な印象をもつようなプ ロセスをとることが多いのではないだろうか。心理学には人の直感 的判断の典型例として、「一目惚れの現象」 ${ }^{16)}$ がある。これは本人 が抱いている理想像の部分と思われる部分的特徵をもつ対象に出 会って、全体像を頭の中に作り上げてしまう思い込みの行動と考え られる。部分から全体を判断する能力は、多属性態度アプロ一チの 及ばない思考である。例えば、我々は映画を見る際、知らない都市 の背景と出会ってもきれいといいながら気詰まりではなくて見る 場合がある。それは本人が抱いている理想像の風景之思われる部分 的特徴をもつ風景に出会って、全体都市の風景を頭の中に作り上げ てしまう「一目惚れの現象」と考えられる。本分析ではこの「一目 惚れの現象」に着目して都市景観類型分析から得られた類型別の画 像を住民に見せて、好みに合って満足できる画像を求め、それをも とにして景観選好注 7) に対する選好意構造を把握してみる。

5. 4. 1 景観類型と居住地域景観の類似性及び満足度

まず、被験者に選好景観を尋ねる前に、景観類型分析から得られ た景観類型が画像データとして住民から認められるかを試してみ た。具体的に類型化された景観 5 類型について各 4 枚ずつの合計 20 枚、図 7 に示す景観画像を用いて評価者が居住している地域との類 似性や景観類型別の満足度について質問した。363 人の被験者の全 員に各類型画像別に類似性を 5 段階で質問した結果、自己の居住地 区と「非常に似ている」という答えは景観類型 1 で $18.5 \%$ あり、 景観類型 2 の場合は $4.1 \%$ 、景観類型 3 は $8.3 \%$ 、景観類型 4 は $5.2 \%$ 、 景観類型 5 は $12.9 \%$ であった。各景観類型の画像に対してはほぼ $50 \%$ 以上住民が自分の地域と「似ている」以上の答えをした。し

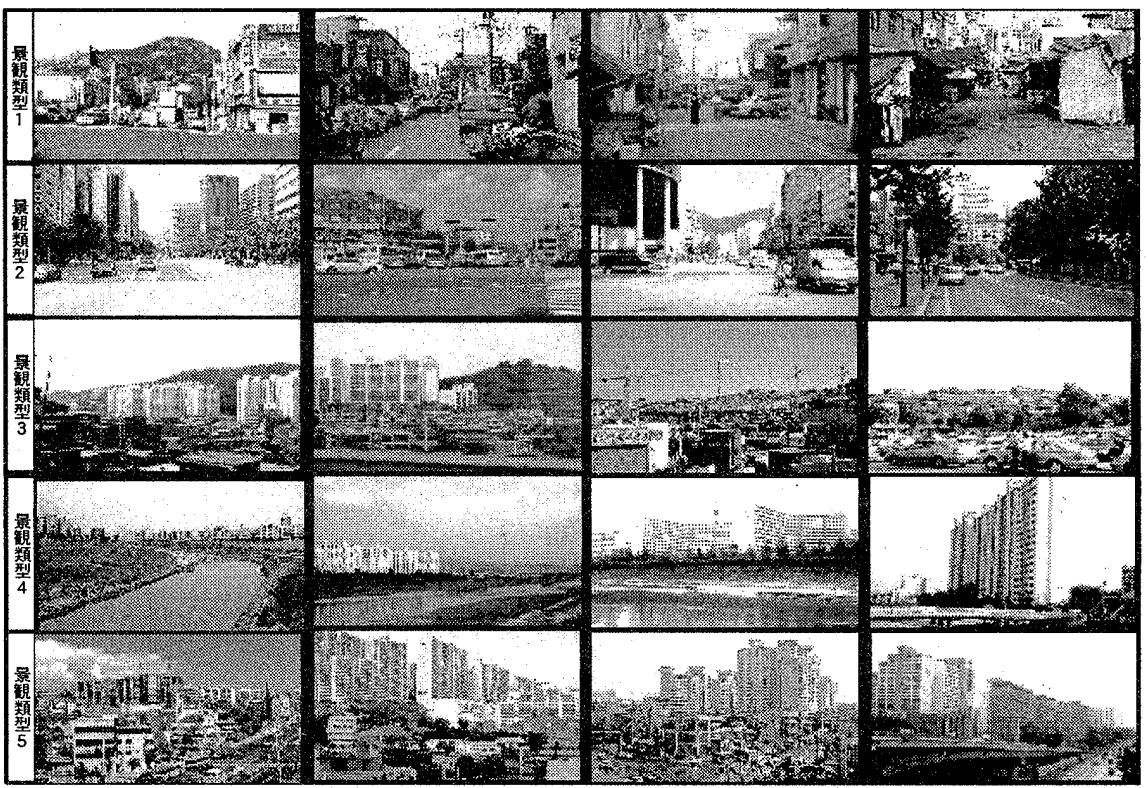

図7. アンケート調査対象画像 
かし、景観類型 4 の場合は「非常に似ている」、似ている」という答 えを合わせても $15.3 \%$ で調查対象地域とは類似性がないことがわ かつた。

なお、景観類型別の景観満足度は「非常に満足」と「満足」の回 答を合計した数值をみると、景観類型 4 と景観類型 2 が $50 \%$ 以上の 高いことを表している。特に景観類型 1 は類似性が高いのに満足度 は低いという逆の現象が表れた。

以上のことを総括すると、調查対象地域の住民は景観類型 1 に対 して類似性を高く感じているが満足度は低く、景観類型 4 に対して は類似性を低く感じているが満足度は高いと考えられる。

\section{4. 2 景観類型による選好景観}

都市景観に対して一般的選好評価構造を把握するために住民の生 活上の諸条件を排除し、ソウルの各地から撮影した景観類型画像の 提示という視覚的判断資料のみを用いる被験者評価実験（SD 法） を行った。その結果を用いて選好される都市景観と選好景観の満足 度の関連を知るために、重回帰分析を通じて選好景観に対する心理 構造を推測する。住民が選んだ選好景観は新林 6 洞以外の地域では 景観類型 4 が最も多い。全体の割合としては 44.6\%の高い値を示し た。表 8 は選択された景観類型の地域別の単純集計である。

\section{4. 3 景観選好評価の因子分析}

景観選好に対する住民の潜在的な意識構造を把握するために測 定法としては評定尺度評価、すなわち、都市に対するイメージや景 観イメージ及び価值観の測定と定性分析には有効な方法と言われ ているSD (Semantic Differential) 法を分析手法に用いた。選好 割合が最も高い景観類型4 (162 名が選択)に対してSD法によるイ メージ評価 (7 段階)を行った。評価項目の選定においては一般住民 である被験者が回答しやすい項目を予備調査を通じて選んだ。まず、 景観類型画像と既存研究を参考にして選んだ 30 項目を見せて、具 体的に景観と関連がない項目や抽象的であっても実際の景観を体 験した場合に評価者が評価しにくいと考えられる項目を除いても らい、最後には 17 項目を選定した。景観選好評価結果には各個人 の評価結果をもとに主因子法、バリマックス回転による因子分析を 適用した。因子数については、2 主成分から 5 主成分までの分析を 行ない、それぞれの結果を得たが、最適解を得たのは、因子数を 4 にしたときであった。第 4 因子注 ${ }^{8)}$ までの累積寄与率は $43.57 \%$ と なった。各因子の意味を考察すると、第 1 因子は「傸やかだーうっ 表8. 地区別の選好景観の単純集計

\begin{tabular}{|c|c|c|c|c|c|c|c|c|}
\hline \multirow{2}{*}{ 地 区 } & \multirow{2}{*}{ 地区特性 } & \multirow{2}{*}{ 割合の项目 } & \multicolumn{5}{|c|}{ 選んた畐钼類型 } & \multirow[b]{2}{*}{ 合 計 } \\
\hline & & & 1 & 2 & 3 & $\frac{x+2}{4}$ & 5 & \\
\hline \multirow{3}{*}{ 東西門洞 } & 高属住宅地域 & 度数 & & 10 & & 25 & 11 & 54 \\
\hline & 丘陵地 & 地区の \% & 1.9 & 18.5 & 13.0 & 46.3 & 20.4 & 100.0 \\
\hline & 住居地域 & 㟟んだ票観類型の \% & 4.3 & 8.9 & 20.6 & 15.4 & 34.14 & 14.9 \\
\hline \multirow{3}{*}{ 東仙洞 } & 商業地域 & 度数 & 2 & 15 & 1 & 28 & 7 & 53 \\
\hline & 平地 & 地区の \% & 3.8 & 28.3 & 1.9 & 52.8 & 13.2 & 100.0 \\
\hline & 商業地域 & 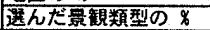 & 8.7 & 13.4 & 2.9 & T1. & 21.9 & 14.6 \\
\hline \multirow{3}{*}{ 貞陵 3 洞 } & 低屬住宅地域 & 度数 & 5 & 20 & - & 27 & - & 52 \\
\hline & 丘陵地 & 地区の％ & 9.6 & 38.5 & - & 51.9 & - & 100.0 \\
\hline & 住居地域 & 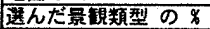 & 21.7 & T.9. & $=$ & 16.7 & - & 14.3 \\
\hline \multirow{3}{*}{ 新林本洞 } & 商業地城 & 度数 & 3 & 19 & & 20 & 4 & 52 \\
\hline & 平地 & 地区の\% & 5.8 & 36.5 & 11.5 & 38 ह & 7.7 & 100.0 \\
\hline & 商業地域 & 選んだ景観類型の \% & 13.0 & 17.0 & 17.6 & 12.3 & 12.5 & 14.3 \\
\hline \multirow{3}{*}{ 新林 6 洞 } & 低層住宅地域 & 度数 & 7 & 19 & 7 & 18 & 4 & 55 \\
\hline & 平地 & 地区の \% & 12.7 & $34 . \mathrm{St}$ & 12.7 & 32.7 & 7.3 & 100.0 \\
\hline & 住居地域 & 選んだ景䆏類型の\% & 30.4 & 17.0 & 20.6 & 11.1 & 12.5 & 15.2 \\
\hline \multirow{3}{*}{ 奉天3洞 } & 高嬖住宅地域 & 喥数 & 3 & 17 & $b$ & 19 & 2. & 47 \\
\hline & 丘陵地 & 地区の％ & 6.4 & 36.2 & 12.8 & 40. 4 & 4.3 & 100.0 \\
\hline & 住居地域 & 㟟んだ量観類型の \% & 13.0 & 15.2 & 17.6 & 11.7 & 6.3 & 12.9 \\
\hline \multirow{3}{*}{ 倉 3 洞 } & 工業・住居地域 & 度数 & 2 & 12 & & 25 & 4 & 50 \\
\hline & 平地 & 地区の \% & 4.0 & 24.0 & 14.0 & 50.0 & 8.0 & 100.0 \\
\hline & 住居·工業地域 & 選んだ景観類型の \% & 8.7 & 10.7 & 20.6 & 15.4 & 12.5 & 13.8 \\
\hline \multirow{3}{*}{ 会 } & & 度数 & 23 & 112 & 34 & 162 & 32 & 363 \\
\hline & 計 & 地区の \% & 6.3 & 30.9 & 9.4 & 44.6 & 8.8 & 100.0 \\
\hline & & 選んだ量観類型の \% & 100 & 100 & 100 & 100 & 100 & 100 \\
\hline
\end{tabular}

とうしい」「開放的だー閉鎖的だ」「静かだーうるさい」「目立つー 目立たない」「滑らかだー荒い」「美しい-醜い」といった形容詞对 の負荷量が大きい、すなわち住民が地域景観の雾囲気から得られる こととして景観の「快適性」を評価する軸であると解釈した。第 2 因子は「特徵がある一特徵がない」「非日常的だー日常的だ」「楽し いーつまらない」「魅力感がある一魅力感がない」といつた形容詞 対の負荷量が大きい、地域景観が住民に見せている視覚的な要因と して景観の「魅力性」を評価する軸であると解釈した。第 3 因子は 「整然だ一雑然だ」「安心だー不安だ」「明るい一暗い」「きれいだ 一污い」といた形容詞対の負荷量が大きい、地域景観の構造から 得られることとして景観の「調和性」を評価する軸であると解釈し た。第 4 因子の場合は「伝統的だー現代的だ」「自然的だ一人工的 だ」「暖かいー冷たい」といった形容詞対の負荷量が大きい、地域 の景観が他の地域景観が比較される場合に意識する要因として景 観の「品位性」を評価する軸であると解釈した。

さらに、因子分析で求めた因子のどの因子が選好景観の満足度に 影響を与えているかを把握するため、景観類型 4 の 5 段階満足度の 評価点 $(Y)$ を目的変数に、得られた 4 因子の因子得点を説明変数に して重回帰分析を行った。その結果を表 10 に示す。

\section{この分析から得られた}

重回帰式は $Y=1.051 X_{1}+0.481 X_{2}-0.038 X_{3}-0.278 X_{4}+4.728$ で ある。なお、各因子のウエイトを求めるため、標準偏回帰係数を算 出したところ、第 1 因子である「快適性」が 0.654 で他の因子と比 ベ、高い值を示した。すなおち、第 1 因子が住民の選好景観の満足 度に強く影響及ぼしており、住民は景観に対して爽やかだなどを主 体とする「快適性」を感じることにより、その心理が景観選好評価 に結びつく心理構造が推測され、景観選好満足評価には「快適性」 が大きなウェイトを占めることが明らかになった。

\section{表9. 景観選好の因子分析結果(因子負荷量)}

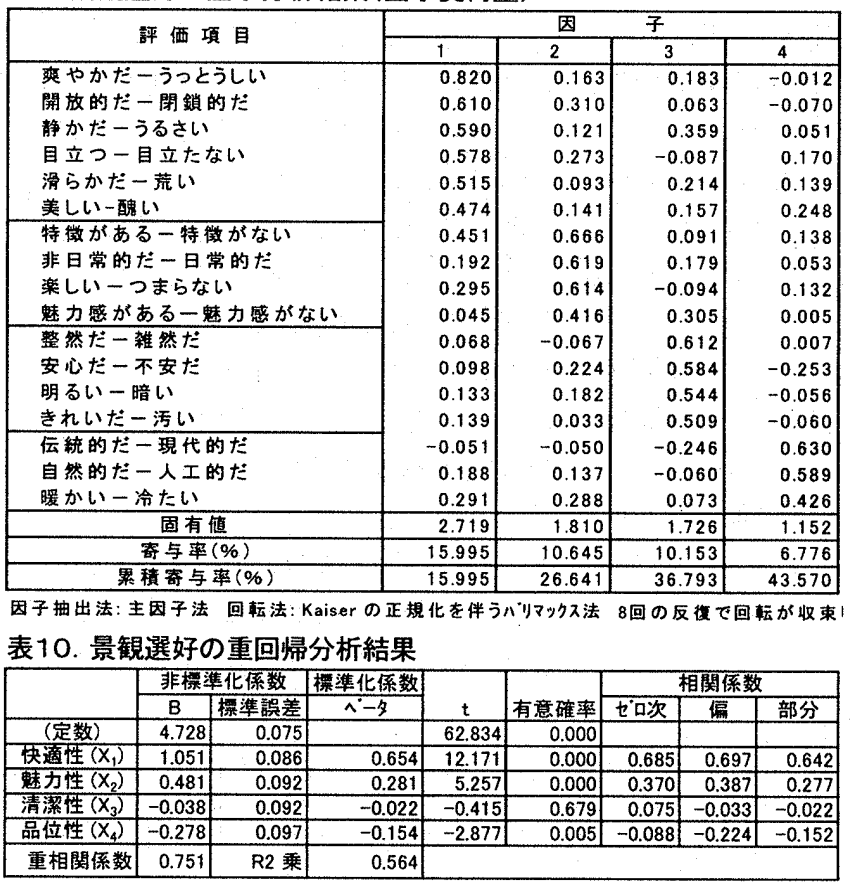

\section{6. おわりに}

本研究では、ソウルを対象として、(1)高密度な都市空間の実態と 
都市景観の空間特性と景観の形態の特徵を明らかにすること、(2)住 民の景観意識を中心とした調查を行って高密度都市住民の基礎的 な景観選好の意識構造を把握することによって高密度な都市景観 について考察することを目的として行った。

その結果、景観形態分析では高層建築物を含む画像が比較的多く 見られ、これら高層建築物がりウルの景観を特徵付けていることが 分かった。景観の類型化によって、次の 5 類型を得ることが出来た。

「低層地域における街路景観小、商業・業務地区における街路景観」 「低層住居を中心とした眺望景観」、「オープンスペースから望む展 望景観小、高密な住宅地景観」である。比較的高層の建築物からな る景観類型 2 に該当する「商業・業務地区における街路景観」の景 観画像が最も多く、景観類型 5 の「高密な住宅地景観」がこれにつ づいており、高密度性がソウルの景観を特幑づけていることが明確 となった。さらに、各類型と用途地域、地形条件との関係を考察し た。景観類型 1 および景観類型 2 は平地の商業地域に、景観類型 3 は丘陵地の緑地地域に、景観類型 4 と景観類型 5 は平野の住居地域 に多く分布していることがわかった。この景観類型分析により、ソ ウルの景観類型別の特徵を、そこに含まれる景観構成要素を通して 認識することができた。

なお、景観選好意識分析ではソウルの密度について住民がどのよ うに感じているかを確認するために、地域密度に対する意識評価を 通じて全地区の被験者が「地域の密度が高い」と感じていることが わかった。その理由としては急速な再開発・再建築事業と深い関係 があることが明確となった。また、「一目惚れの現象」を用いた選 好景観に対する評価を通じて、「オープンスペースから望む展望景 観」の景観類型 4 が調查対象地域とは類似性がないが選好度はたい へん高いことがわかった。

景観類型 4 を用いた因子分析の結果、第 1 因子は「快適性」、第 2 因子は「魅力性」、第 3 因子は「調和性」、第 4 因子は「品位性」を 評価する軸であると解积した。また、得られた因子分析から景観選 好意識の構造を明らかにするために、各因子得点と満足度を用いて 重回帰分析を行った。その結果、住民が選好景観を評価する際には 「快適性」が大きく影響することが明らかになった。

総合的に考察すると、近年住宅地の高層化が進み高密な空間利用 しているソウルでは大きな特徵になっている丘陵地を生かす必要 がある。そのために、景観類型 4 に分類される河川やオープンスペ 一スから見渡せる景観を重視し、公園などのオープンスペースを都 市の高密な空間と調和できるようにすることが望ましいと考えら れる。また、これにより市民の満足感を高め、さらによりよい都市 景観形成に奇与すると考えられる。

なお、本研究は都市部に展開する希少な景観まで含めて類型化し てはいない。また、オープンスペース整備方法その景観方策などを 十分に検討することが必要であり、今後の課題として残っている。

\section{謝 辞}

本研究は、松原 恒氏（現山口県庁、当時大分大学大学院博士前期課程） のご協力によるところが大きいでした。また、本研究に対しソウル市立大学 の金基虎先生と西京大学の李承柱先生に御助言いただきました。ここに記し て、謝辞にかえさせていただきます。

なお、本研究は大分大学都市計画研究室と韓国・西京大学都市工学科よる 文部科学省科学研究費補助金（基盤研究 C(2)）「高密度都市空間における景観 誘導と景観阻害要因の発生メカ二ズム」（課題番号 10045047）の一環として 行われたものである。
注

1) 開発制限区域(Green Belt)というのは都市の無秩序な拡散を防止し、都市周 辺の自然環境を保存して、市民の健全な生活環境を確保することを目的と する区域である。初めて 1971 年に指定されて、1999年現在は $166.82 \mathrm{~km}^{2}$ (市 全体面積の $27.6 \%$ )が指定されている。しかし、最近は不正的側面(市民生活 に不便など)が強調されて市民と市の紛争要因になっている。

2）1998 年現在、ソウルの都市計画における用途地域は住居地域(住居専用/一 般住居/一種住居/二種住居/準住居) $300.70 \mathrm{~km}^{2}$ 、商業地域(中心商業/一般商業 /近隣商業/流通商業) $23.05 \mathrm{~km}^{2}$ 、工業地域(専用工業/一般工業/準工業) $29.00 \mathrm{~km}^{2}$ 、緑地地域 $249.65 \mathrm{~km}^{2}$ (保全緑地/自然緑地/生産緑地) 乙して 15 種類 が指定されている。本研究では用途地域を大きく 4 種類に分けて調査地域 を抽出した。

3）撮影時刻は $\mathrm{am} 7: 00 \sim \mathrm{pm} 4: 00$ までとし、夕刻での写真撮影は写真が赤焼け するため、原則として禁止した。また、同じ形態の写真を得るため $50 \mathrm{~mm}$ レンズを使用して横向きに撮影した。

4）密度に関する議論の基本は人口 密度であり、そこから各種密度指 標が分化されている。現在、我々 の生活でよく使われている密度 は土地人口密度 (人口/土地) で ある。しかし、これでは複雑な環 境や都市構造を持っている現代 都市の特性を調べるのは難しい。 また、比較的限られた住宅地で議

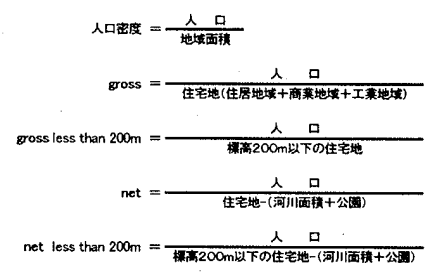
論するときは、分母分子のとり方を明確にする必要がある。それで、本研 究では分母分子のとり方を明確した多様な密度測定の指標を用いて、ソウ ルにおける各区の密度を調べた。

5）アンケートの予備調查は大分大学・別府大学のソウル出身の留学生 11 名 を対象にして行われた(1999 年 8月 16〜17日)。また、韓国語の形容詞対を 使用したので、日本語の翻訳では十分に理解できるかについて韓国からの 留学生によるワークショップも行った。

6）ヴィラ（Villa）と連立住宅と多世帯住宅は韓国の共同住宅の種類であり、 一般に庶民向きの住宅である。あまり大きいヴィラ(Villa)団地はなく、ほと んどが 4 階以下の低層形態である。

7）本研究では選好は「あるものを他よりも好むこと」と定義する。また、参 考文献 16 によると、好みは3つに分けられる。一番強いのは嘴好度 (liking)、 「絶対にこれでなくてはならない」という状態、次のは選好度 (preference) で、「相対比較してこちらのほうがよいと選択する」状態、通常の商品の選 択は殆どこの選好度で行われていると考えてよい。3番目は受容度 (acceptability)、「これでもいい、がまんできる」という判断である。本研 究の選好度は 2 番目の選好度（preference）を意味している。

8）第 5 因子は初期の固有値が 0.96 になつて累積奇与率が上がらず、第 4 因 子と差が大きいため因子数を 4 にした。

\section{参考文献}

1）村川三郎、西名大作 : 住民意識による都市内河川環境評価の分析－河川環 境評価手法に関する研究 その1、日本建築学会計画系論文報告集第 366 号、 pp.42 51、1986

2）西名大作、村川三郎他 : 住民による地域の伝統的みどり景観の評価構造に 関する研究、日本建筑学会計画系論文報告集、第 509 号、pp.77〜84、1998

3）土肥博至、田中奈美、澤田幸枝、鈴木理恵 : 景観単位による地域景観の記 述方法、第 30 回日本都市計画学会学学術研究論文集、pp.229〜233、1995

4）上杉和也、中川義英他：地区イメージを考慮した地区景観評価に関する研 究、第 28 回日本都市計画学会学学術研究論文集、pp.601 606、1993

5) 坂本淳二：混在化地域における景観域の把握とその類型化、日本建築学会 計画系論文報告集、第 504 号、pp.127〜134、1998

6）佐藤誠治他：釜山市における景観保全に関する基礎的研究第、20 回情報 システム利用技術シンポジウム論文集、pp.223-228、1997

7) 萩島哲, 出口敦, 鵤心治：19 世紀ヨ一ロッパ風景画にみる都市景観に関す る研究、日本建築学会計画系論文報告集、第 413 号、pp.83〜93、1990

8）川崎 清、平尾和洋他：「好きな景観」写真展にみる景観読解過程と景観 タイプ、日本建築学会計画系論文報告集、第 472 号、pp.123 132、1995 9）土肥博至、上山 彈: 写真投影法を用いた景観評価の基礎的構造に関する 研究、第 31 回日本都市計画学会学術研究論文集、pp.595-600、1996

10）有馬隆文、佐藤誠治、萩島哲他：3次元 CG を用いた景観特性の計量化 とそのシステム開発に関する研究、日本建築学会計画系論文報告集、第 523 号、pp.227〜234、1998

11）佐藤誠治他: 3 次元コンピュータグラフイックスを用いた山並み保全に関 する研究一釜山市におけるマク口的䁬望景観分析、第2 2 回情報システム利 用技術シンポジウム論文集、pp.163-168、1998

12）ソウル市政開発研究院：ソウル市都市景観管理方案 I、1993

13）ソウル市政開発研究院：ソウル市都市景観管理方案 II 1994

14）ソウル市政開発研究院 : ソウル市都市景観管理方案III、1997

15）ソウル市政開発研究院：丘陵地における再開発アパートの代案的形態開 発、 1997

16）魅力工学研究フォーラム編、「魅力工学」、海文堂出版、1992 